\title{
Private concession contracts for toll roads in Spain: analysis and recommendations
}

\section{María de los Ángeles Baeza and José Manuel Vassallo}

Spain has a long history of using the private sector to help build and operate public infrastructure, particularly roads. This article presents new data about toll motorways. The authors found that contracts in Spain are characterized by significant traffic overestimations and frequent renegotiations, which can lead to toll modifications or longer contracts. They suggest reasons for this and some solutions-both of which have significance for other countries.

New means of involving the private sector in managing and financing public infrastructure through public-private partnerships (PPPs) and concession contracts are emerging in many countries. There are three main reasons for this:

- Tightening public finances.

- Greater productivity efficiency.

-Quality improvement (OECD, 2008).

One of the most common ways of implementing private participation in managing infrastructure is through the concession approach, which involves transferring the design, construction, maintenance, and operation of the infrastructure to a private consortium. The consortium then has the right to charge a user fee, for a period of time contractually agreed in advance (Vassallo and Gallego, 2005).

This article analyses key variables in Spanish motorway concession contracts. We evaluate the ultimate accuracy of cost estimates made by the concessionaires. Then we analyse how frequently contracts were renegotiated, and what prompted these renegotiations. We found a consistent bias towards traffic overestimation and capital cost underestimation. In addition, there was a distinctly high number of renegotiations of concession contracts in Spain. Once a government gets a track record of renegotiating concession contracts, bidders in competition may submit low tenders.

\section{Risks, estimations and renegotiation}

Risk allocation principles

Risks in concession contracts reflect the inability of the stakeholders to know upfront the evolution of the variables which determine the outcome of the concession business throughout the life of the contract. As Sirtaine et al. (2005) point out, concession contracts are regarded by the private sector as an attractive but highly risky business. Concession contracts are also risky for the government insofar as public guarantees by the government are provided.

Toll motorway concessions are subject to several types of risk:

- Capital cost risk (land acquisition, construction and license approval).

- Revenue risk.

- Maintenance and operational risk.

According to the nature of the risk, we can classify the risks as market risks, force majeur and unpredictable risks, and legal and political risks (Izquierdo and Vassallo, 2004).

There is an extensive literature regarding risk allocation in concession contracts (Loosemore, 2007; Medda, 2007). According to the World Bank (1997), risk allocation in concession contracts should take into account ability to get the best outcome and ability to manage the risk at the lowest cost. Market risks are usually allocated to a concessionaire, whereas governments generally take on force majeur, political and legislative risks.

Risk allocation has a strong relationship with the financial cost of a project. The greater the risk allocated to the concessionaire, the higher the financial cost of the project. When the risks allocated to the concessionaire are very high, the financial cost of projects become significant, which can threaten the ultimate financial feasibility of the project. This is the reason why public guarantees are often provided. These guarantees facilitate the financial feasibility of the project at the expense
María de los Ángeles Baeza is Senior Lecturer at the University of Granada, Spain.

José Manuel Vassallo is an associate professor at the Universidad Politécnica de Madrid, Spain. 
of allocating a greater risk to the government.

How to allocate traffic nisk?

Estimating traffic risk in motorway concessions is difficult. Adistinction needs to be made between 'brownfield' projects (concessions based on an existing facility) and 'greenfield' projects (concessions that have to be built from scratch). Of course, estimating traffic in brownfield projects is much easier than in greenfield projects.

Once a project is operational, the evolution of traffic throughout the life of the concession depends mostly on variables that are outside the control of the concessionaire, such as economic growth, urban development, competition with other transport modes, and so on. Nevertheless, the concessionaire is still able to influence the evolution of traffic through pricing measures, information to the users, quality of service and so on.

There is a controversy regarding the stakeholder to whom traffic risk should be allocated inconcession contracts. Somecountries, such as the UK in its DBFO contracts, have tended to progressively untie the revenues obtained by the DBFO contractor from traffic by linking revenue to performance-based indicators in terms of safety, availability and so on. Other countries, such as Spain, France, Italy, the USA and many Latin America countries, tend to allocate traffic risk in concession contracts, at least in part, to the private sector (Izquierdo and Vassallo, 2004). More recently, many countries have started to introduce mechanisms in their contracts to share traffic risk between the private and the public sector (see Vassallo, 2006).

\section{Accuracy of predicting traffic flow and costs}

In this section we analyse the inaccuracy of the estimation of traffic and capital investment. We focus on traffic and capital investment because they are the most important factors in terms of profitability.

The largest study dealing with forecasting accuracy for transport projects was conducted by Flyvbjerg et al. (2005). In this study 210 projects ( 183 of them road projects) were analysed in 14 countries. Most of these projects were publiclyprocured projects, so traffic projections were conducted by the government. It was found that traffic was generally not overestimated in road projects when the projections are conducted by governments.

The most complete study dealing with traffic forecasting accuracy in toll road concessions was done by Bain and Polakovic (2005) and was based on 104 toll roads. Toll road concessionaires were found to overestimate first year traffic by
$20 \%$ to $30 \%$. This study also demonstrated that bank-commissioned forecasts were consistently less prone to large errors than those commissioned by bidders. This result suggests that the lack of accuracy in the estimation of traffic is not just linked to modelling.

Regarding cost overruns in transport infrastructure projects, the broadest study was conducted by Flyvbjerg et al. (2004). This study, based on a sample of 258 projects (rail, bridge, tunnel and road projects), found cost overruns of $34 \%$ in PPP projects and $110 \%$ in state-owned enterprises compared with $23 \%$ for publiclyowned projects. This study concludes that the claim that public ownership is problematic and private ownership is effective in curbing cost escalation is an oversimplification.

\section{Renegotiations of contracts}

The word 'renegotiation' usually has a negative connotation. However, renegotiations do not necessarily produce a negative final outcome for the public sector. A renegotiation could be in the public interest if all the stakeholders involved are better off after the renegotiation takes place (Huberman and Kahn, 1988). However, as Hooper (2008) points out, renegotiation is detrimental if it is anticipated by the operator when submitting the first bid. Most of the conflicts in concession contracts have been solved by renegotiation, which explains why most of the failed contracts have never been terminated (Harris, 2003).

Guasch (2004) studied more than 100 concession contracts awarded in Latin America from 1985 to 2000 . The percentage of transport concessions that were renegotiated was $54.7 \%$. These renegotiations mostly benefited the concessionaires. Renegotiations are much more common in those concessions awarded competitively than in those concessions awarded through direct negotiation (Guasch et al., 2008). Thisresult can be seen as an empirical explanation of what is called 'the winner's curse' (Hong and Shum, 2002), where aggressive bids in competitive tenders lead to low bids by the concessionaire.

\section{Bias}

There are several ways of procuring concession contracts. The two most popular approaches are the 'open procedure' and the 'negotiated procedure', as defined by EU legislation. The open procedure involves granting the concession to the best offer in terms of a set of criteria defined by the government in advance. Any consortium that meets the bidding requirements fixed by the government (generally involving 
experience inoperating motorways and financial strength) is allowed to bid. Before the tender takes place, the government writes a standard contract, which will establish the future relationship with the eventual concessionaire. This standard contract is mostly fixed by the government with the exception of some specific aspects, which are to be completed by the bidders in their written offer. These aspects are the criteriaon the basis of which the government will decide the best offer.

The negotiated procedure is based on a negotiation between the government and a few preferred bidders who have been prequalified by the government. Unlike the open procedure, contractsare not standard-theyare tailor-made.

The open procedure is more common in civil law countries such as Spain or Germany. The negotiated procedure is more usual in common law countries such as the UK, even though it has also been implemented in some civil law countries, for example Portugal.

The open procedure has advantages and drawbacks compared to the negotiated procedure. Tendering costs are lower in the open procedure (Sánchez-Soliño and Gago, 2010), however, the contract will not be as complete as a negotiated contract.

A report by Silva (2000) points out that one of the reasons why some concession contracts ultimately fail is due to traffic overestimation. He shows how these projects have to be often renegotiated. Moreover, Athias and Nuñez (2008) show that bidders tend to bid more aggressively and strategically in institutional frameworks in which renegotiating is easier. Consequently, a government's willingness to renegotiate is crucial for the bidders in their decision to commit strategic errors.

According to Ping Ho(2006), ifagovernment is willing to renegotiate, it implicitly encourages aggressive bidding. This situation may cause a 'vicious cycle' in the concession tender since competition for concession contracts is fierce-if governments show a historical track record of renegotiation, bidders will be encouraged to inflate their forecast to justify aggressive offers in order to increase their possibilities of winning the tender. Once the contract is secured, the concessionaire assumes that the government will renegotiate the agreement.

Inefficient renegotiations in concession contracts end up being very costly for either users or taxpayers. Renegotiations often lead to subsidies by the government or changes in the concession contract that lead to tolls increases or extension in the length of the contracts (Guasch, 2004). This is the reason why this behaviour should not be called the 'winner's curse' but, rather, the 'user's or the taxpayer's' curse since the users or the taxpayers will be the ones who, in the end, will suffer the consequences of the renegotiation.

\section{Case study}

Spain has a long experience of toll motorway concessions (Acerete $e t$ al., 2009) and has passed laws governing these contracts. Since 1967 , the Spanish government has granted 32 toll motorway concessions. There are two distinct periods in thehistory of toll motorway concessions in Spain (Vassallo and Sánchez-Soliño, 2007). In the first period, from 1967 to 1975,15 motorway contracts were awarded. The Toll Motorway Concession Law was passed in 1972 to regulate contracts.

Between 1976 to 1995 , concessions were not used for public infrastructure in Spain. The Socialist government opted to modernize the road network by widening and upgrading the most important roads, turning them into dual carriageways (double lane fast roads) with quality standards well below those for toll motorways. This new programme was completely funded by the public sector (Izquierdo, 1997).

The second period is from 1996 to the present. During thissecond period, the governing People's Party (Partido Popular) re-introduced the concession model. This trend towards private funding was reinforced by a new Public Works Concession Law, passed in 2003, which widened and updated the Toll Motorway Concession Law 1972. In 2004, the Socialist Party and the concession mechanism was reintroduced as a means of financing public infrastructure.

\section{Features of comcession contracts in spain}

Toll motorway concessions in Spain have had the same distinctive features over the years, even though there are some differences between the concessions awarded in the first period (19671975) and the concessions awarded in the second period (from 1996).

Unlike other long-term infrastructure contracts in the world (for example DBFO contracts in the UK or Portugal), toll concession contracts in Spain are awarded on the basis of the open procedure. The concession contracts are consequently rather incomplete, since they are based on standard contracts rather than on tailor-made contracts.

Maximum toll levels are established in the concession contracts and tolls can be updated every year in line with inflation. However, from 2000 onwards, a mechanism allowing greater toll increases if traffic was lower than 
expected was introduced (Bel and Fagueda, 2005).

\section{Accuracy of the estimates and renegotiations}

Information about the performance of toll motorway concessions in Spain is sparse and difficult to obtain (Acerete et al., 2009). One of the major contributions of this article, therefore, is the up-to-date dataset. We were able to obtain this data because we had access to the financial plans submitted by the concessionaires in their tenders, which until recently had not been disclosed. We obtained the financial plans, in which traffic and capital cost estimates were included, from the archives of the Ministerio de Fomento (Spanish Ministry of Public Works).

In addition, we investigated renegotiations and their causes based on the information published in the Official Diary of Spain. Table l shows the concession contracts that were ultimately renegotiated; the number of renegotiations (broken down into renegotiations where causes were published and unpublished); and the number of years from the concession award to the first renegotiation. Table 2 shows the final outcome of the renegotiations where causes are published. Most of the renegotiations ended up with either toll modifications or extensions to the length of the concession.

To accurately analyse toll motorway concessions in Spain, the concessions awarded during the first period (1967-1975) and the concessions awarded in the second period (from 1996) must be looked at separately. Regarding the first period, we have only traffic predictions for two concessions: Tarragona-Valencia (awarded in 1971) and Valencia-Alicante (awarded in 1972). Those predictions were conducted by the concessionaire and were included in the projects' business plans. On average, real traffic was less than $50 \%$ of the traffic predicted throughout the life of the contract. There were four reasons for this bad result: the projects were greenfield projects so traffic was difficult to estimate; traffic modelling tools were not very sophisticated at this time; the world economic crisis reduced Spain's GDP growth expectations; and fierce competition led the bidders to make aggressive bids. This latter issue can be confirmed by the fact that in the first years of operation, when there was no economic crisis, traffic flows were substantially lower than expected.

So how were these concessionaires able to survive since traffic was by far the most important revenue source to recover the initial investment? The answer is that the TarragonaValencia and the Valencia-Alicante contracts were renegotiated up to nine times each. The concession term, which was originally fixed for 27 years for both concessions, was extended to 47 and 48 years respectively.

Renegotiations were common in the toll motorway concessions in Spain awarded in the first period, with some contracts being renegotiated up to 14 times. Almost all the concessions ended up with an extension of the duration initially agreed in the contract. Even though the renegotiations were published in the Official Diary of Spain, the causes were often not explained-55 out the 121

Table 1. Renegotiation of concession contracts in Spain.

\begin{tabular}{|c|c|c|c|c|c|}
\hline Name of motorway & $\begin{array}{l}\text { Concession } \\
\text { period }\end{array}$ & $\begin{array}{c}\text { No. of renegotiations } \\
\text { where cause was } \\
\text { published }\end{array}$ & $\begin{array}{c}\text { No. of renegotiations } \\
\text { where cause was } \\
\text { not published }\end{array}$ & No. of renegotiations & $\begin{array}{l}\text { Years until the first } \\
\text { renegotiation took plare }\end{array}$ \\
\hline Barcelona-La Junquera & First $1967-75$ & 2 & 7 & 9 & 17 \\
\hline Mongat-Mataró & First $1967-75$ & & & & \\
\hline Barcelona-Tarragona & First $1967-75$ & 2 & 5 & 7 & 16 \\
\hline Montuneló-El Papiol & First $1967-75$ & 3 & 3 & 6 & 4 \\
\hline Zaragoza-Mediterráneo & First $1967-75$ & 3 & 3 & 6 & 9 \\
\hline Villalba-Villacastín & First $1967-75$ & 7 & 2 & 9 & 13 \\
\hline Villacastín-Adanero & First $1967-75$ & 7 & 1 & 8 & 9 \\
\hline Bilbao-Behobia & First $1967-75$ & 5 & 4 & 9 & 14 \\
\hline Burgos-Málzaga & First $1967-75$ & 7 & $\underline{q}$ & 9 & 5 \\
\hline Sevilla-Cádiz & First $1967-75$ & 3 & 4 & 7 & 8 \\
\hline Tarragona-Valencia & First $1967-75$ & 3 & 6 & 9 & 10 \\
\hline Valencia-Alicante & First $1967-75$ & 5 & 4 & 9 & 5 \\
\hline El Ferrol-F, portuguesa & First $1967-75$ & 7 & 7 & 14 & 1 \\
\hline Bilbao-Zaragoza & First $1967-75$ & 7 & $\underline{q}$ & 9 & 5 \\
\hline León-Campomanes & First $1967-75$ & 5 & 3 & 8 & 6 \\
\hline Málaga-Estepona & Second 1996-2008 & & 1 & 1 & 4 \\
\hline R-4 Madrid-Ocaña & Second 1996-2008 & & 1 & 1 & 3 \\
\hline Total & & 60 & 55 & 121 & \\
\hline
\end{tabular}


renegotiations were not attributed to any specific cause.

For the concessions in the second period, we found that traffic overestimations by the concessionaires were still a common trend in motorway concession contracts, although on average the overestimation was not as large as it was in the contracts awarded in the first period (see table 3). The levels of traffic overestimation were especially high for suburban concessions around Madrid Metropolitan Area (Radial 2, Radial 4, Radial 3 and 5, and the new access to Madrid Barajas Airport) overestimations were between $52 \%$ and $63 \%$.

In terms of renegotiation of concession contracts, the trend in the second period is quite different, since only two concessions have been renegotiated to date (although some are likely to be renegotiated soon-see Arenes [2009]). This may be because these concessions are still quite recent or because Spanish concessionaires are strong companies that own a portfolio of concessions within which there are old concessions that are currently generating plenty of cash so they can weather a poorlyperforming contract (Ministerio de Fomento, 2007).

Apart from traffic, we also conducted an analysis of the accuracy of the capitalinvestment predictions in the first and the second period (see table 3). In the first period, we obtained information of seven concessions out of 10 , so the sample is much better than it is for traffic analysis. We were able to evaluate the whole sample for the second period. The results show a trend towards underestimating capital investment costs. In other words, cost overruns were reported. In the first period, concessions had on average cost overruns of $15.5 \%$ whereas, in the second period, concessions had on average cost overruns of $11.8 \%$. A trend towards underestimating capital investment was detected, but this trend is slightly smaller than the average cost overruns estimated by Flyvbjerg $e t a l$. (2004) for an international world of PPPs. So motorway concessionaires in Spain are not underestimating capital investment more than the average of private concessionaires in other countries.
Table 2. Outcome of renegotiations.

\begin{tabular}{lc}
\hline Outcome & $\begin{array}{c}\text { Percentage of } \\
\text { renegotiations }\end{array}$ \\
\hline Toll modification & $50 \%$ \\
Extension of the concession duration & $24 \%$ \\
Other outcomes & $26 \%$ \\
\hline
\end{tabular}

\section{Discussion and conclusions}

This article shows that toll motorway concession contracts in Spain are characterized by two features: significant traffic overestimations and frequent renegotiations. A considerable percentage of the renegotiations can not be attributed to any cause, and most of them resulted in higher tolls or longer contracts.

We attribute this behaviour to two causes. First, the 'winner's curse', which can be accentuated when bidders know that a government is willing to renegotiate; and, second, to the allocation of traffic risk to the concessionaires when this risk is something they cannot manage. Renegotiations generally impact users (higher tolls) and taxpayers (longer concession periods or government subsidies). This is the reason why we think it would be better to call this phenomenon the 'user's curse' or the 'taxpayer's curse' instead of the 'winner's curse'.

Neither users nor taxpayers have tended to complain very much about this situation. On the one hand, the government does not give much publicity to the renegotiation processes, and explanations are not given. On the other hand, Spain does not have a regulator to defend the interests of the users and the taxpayers in the concession contracts.

The user's curse and lack of regulation is in need of systematic policy treatment. There may be merit, for example, in removing the dependency of concessionaire revenues on the actual traffic flow. This might be achieved with the introduction of other payment approaches, such as the ones implemented in the UK where the contractor's revenue primarily depends on performance, and through traffic risk mitigation mechanisms such as the Least Present Value of the Revenues (Engel et al., 1997) implemented in Chile. There may also be merit in the creation of an independent regulator to

Table 3. Accuracy of traffic and capital cost estimates and percentage of concessions renegotiated.

\begin{tabular}{ccc}
$\begin{array}{c}\text { Traffic estimate accuracy } \\
\text { (real-forecast)/forecast }\end{array}$ & $\begin{array}{c}\text { Aierage capial cost } \\
\text { estimate accuracy } \\
\text { (real-forecast)/forecast }\end{array}$ & $\begin{array}{c}\text { Percentage of concessions } \\
\text { renegotiated }\end{array}$ \\
\hline$-62.51 \%$ & $15.43 \%$ & $100 \%$ \\
$-95.28 \%$ & $11.83 \%$ & $17 \%$ \\
\hline
\end{tabular}


represent the interests of users and the taxpayers when a renegotiation process is initiated.

\section{References}

Acerete, B., Shaoul. J. and Stafford. A. (2009), Taking its toll: the private financing of roads in Spain. Public Money \& Management, 29. 1, pp. 1926.

Arenes, S. (2009), Fomento negocia para evitar la quiebra de lasautopistas radiales. Público (9 June), p. 27.

Athias, L. and Nuñez. A. (2008). Winner's curse in toll road concessions. Economic Letters, 101.3, pp. $172-174$.

Bain, R. and Polakovic, L. (2005), Traffic forecasting risk study. European Transport Conference (Strasbourg).

Bel. G. and Fagueda, X. (2005), Is a mixed funding model for the highway network sustainable over time? In Ragzi, G. and Rothengatter, W. (Eds), Procurement and Financing of Motoruays in Europe (Elsevier, Amsterdam).

Engel, E.. Fischer, R. and Galetovic, A. (1997), Highway franchising: pitfalls and opportunities. American Economic Review, 87. 2, pp. 68-72.

Flyvbjerg, B.. Skamris Holm, M. K. and Buhl, S. L. (2004). What causes cost overruns in transport infrastructure projects? Transpont Reviews, 24, 1 . pp. $3-18$.

Flyvbjerg, B.. Skamris Holm. M. K. and Buhl, S. L. (2005). How (in)accurate are demand forecasts in public works projects? Joumal of the American Planning Association, 71, 2. pp. 131-146.

Guasch. J. L. (2004), Granting and Renegotiating Infrastructure Concessions: Doing it Right (World Bank, Washington, D.C.).

Guasch. J.. Laffont, J. and Straub, S. (2008), Renegotiation of concession contracts in Latin America. Intemational Joumal of Industrial Organization, 26, pp. 421-44․

Harris, C. (2003), Private Participation in infrastructure in Developing Countries (World Bank. Washington, D.C.)

Hong, H. and Shum, M. (2002), Increasing competition and the winner's curse. Review of Economic Studies, 69. pp. 871-878.

Hooper, L. (2008), Paying for performance. Research in Transportation Economics, 22, pp. 157-163.

Huberman, G. and Kahn, C. M. (1988), Strategic renegotiation. Economic Letters, 28, pp. 213-246. Izquierdo, R. (1997), Gestión y Financiación de Infraestructuras de Transporte Terrestre (Asociación Española de la Carretera. Madrid).

Izquierdo, R. and Vassallo, J. M. (2004), Nuevos sistemas de gestión y financiación de infraestructuras de transporte (Colegio de Ingenieros de Caminos. Canales y Puertos, Madrid).

Loosemore, M. (2007), Risk allocation in the private provision of public infrastructure. Intemational Joumal of Project Management, 25, pp. 66-76.

Medda, F. (2007), A game theory approach for the allocation of risks in transport PPPs. Intemational Joumal of Project Management, 25. pp. 213-218.

Ministerio de Fomento (2007), Memoria de la delegación del Gobiemoen las Sociedades Concesimarias de Autopistas de Peaje (Madrid).

OECD (2008), Transport Infrastructure thuestment: Options for Efficiency (Paris, France).

Ping Ho, S. (2006). Model for financial renegotiation in PPP projects and its policy implications. Joumal of Construction Engineering and Management, 132, 7, pp. 678-688.

Sánchez-Soliño.A and Gago, P. (2009). Transaction costs in transport public-private partnerships: comparing procurement procedures. Transport Revieuts, 30, 3, pp. 389-406.

Silva, G. F. (2000), Toll Roads: Recent Trends in Private Participation (World Bank. Washington. D.C.).

Sirtaine, S., Pinglo, M. E., Guasch, J. L. and Foster. V. (2005), How profitable are private infrastructure concessions in Latin America? Empirical evidence and regulatory implications. Quarterly Review of Economics and Finance, 45, pp. 380-402.

Vassallo, J. M. and Gallego, J. (2005), Risk-sharing in the New Public Works Concession Law in Spain. Transportation Research Record 1932, pp. 18.

Vassallo, J. M. (2006), Traffic risk mitigation in highway concession projects: the experience of Chile. Joumal of Transport Economics and Policy. 49. 3. pp. 359-381.

Vassallo, J. M. and Sánchez-Soliño, A. (2007). Subordinated public participation loans for financing toll highway concessions in Spain. Transportation Research Record 1996, pp. 1-9.

World Bank (1997), Global Development Finance (Washington. D.C.). 